\title{
MANAJEMEN BARANG MILIK DAERAH BERBASIS KEMITRAAN DALAM MENINGKATKAN SUMBER PENDAPATAN DAERAH
}

\author{
Yasin'1, Fadillah Putra ${ }^{2}$, Oscar Radyan Danar ${ }^{3}$ \\ 1,2,3 Universitas Brawijaya \\ *Korespondensi: yasinsaon@gmail.com
}

Article Histori:

Accepted: 9/10/2020

Review: 19/10/2020

Publish: 31/10/2021

\section{Abstract}

The purpose of this study is to examine partnership-based regional property management in increasing local revenue sources for the Bima Regency government, and to analyze the factors that support and hinder partnership-based regional property management in realizing an increase in regional original income with the concept of Collaborative Governance. This type of research is a qualitative research that was chosen to describe the implementation of regional asset management in the form of leased land carried out by the DPPKAD Bima Regency, West Nusa Tenggara (NTB) using interactive model data analysis from Miles, Huberman and Saldana. The results showed that in general, partnership-based regional property management in increasing local revenue sources at the DPPKAD Bima Regency did not go well but showed an increase in regional original income, with supporting factors, among others; good quality/level of human resources education, a supportive work environment, and adequate infrastructure. While the inhibiting factors are regulations that do not reach the partnership process and the low level of program socialization.

Keyword: Public Management, Partnership, Collaborative Governance

\section{PENDAHULUAN}

Reformasi keuangan pada negara ini bergulir mulai tahun 2003, bentuk komitmen pemerintah ousat untuk memenuhi prinsip tata kelola pemerintahan baik (good governance) melalui pengelolaan keuangan yang sehat dan maju. Perubahan dilakukan secara menyeluruh, termasuk dalam hal pengelolaan aset negara. Secara umum, arti kata" aset negara" memiliki makna yang sama dengan Barang Milik Negara/Daerah (BMN/D) atau asset yang diperoleh dari alokasi APBN/APBD atau yang berasal dari perolehan sumber yang lain. Barang Milik Daerah merupakan salah satu unsur sangat penting dalam rangka penyelenggaraan pemerintahan, pembangunan, pemberdayaan serta pelayanan publik. Maka pemerintah harus melakukan pengelolaan manajemen dengan baik dan benar supaya terdorong perwujudan peningkatan manfaat dari kekayaan tersebut, dengan memperhatikan asas fungsional, asas kepastian hukum, asas kepatian nilai, asas efisien, asas transparansi dan asas akuntabilitas.

Soleh dan Rochmansjad (2010:174) mengatakan bahwa aset milik daerah merupakan semua kekayaan daerah baik yang dibeli maupun didapatkan atas beban APBD (Anggaran Pendapatan dan Belanja Daerah), ataupun yang berasal dari perolehan lainnya, bergerak maupun tidak bergerak, beserta bagian-bagianya yang merupakan satuan tertentu yang dapat dinilai, dihitung, diukur atau ditimbang tak terkecuali uang dan surat-surat berharga lainnya. Adapun sumber-sumber lain dari barang milik daerah dapat berasal dari 
bermacam-macam sumber adalah Pembentukan Daerah Otonom Berdasarkan Perundang-Undangan, pembelanjaan APBN/APBD, sumbangan dalam negeri maupun luar negeri, sumbangan pihak ketiga, penyerahan dari pemerintah pusat serta swadaya masyarakat, dan semua barang yang secara hukum dikuasai pemerintah daerah.

Untuk menunjang pengelolaan BMD (Barang Milik Dearah), perlu adanya kesamaan persepsi dan langkah secara tersusun dan menyeluruh dari unsur-unsur yang berkaitan dengan pengelolaan barang milik daerah. Sehingga pemerintah mengeluarkan dan mengesahkan Peraturan Menteri Dalam Negeri Nomor 19 Tahun 2016 tentang Pengelolaan Barang Milik Daerah, di mana sebelumnya pemerintah pusat mengeluarkan Peraturan Pemerintah Nomor 27 Tahun 2014 tentang Pengelolaan Barang Milik Negara/Daerah, disempurnakan dan dipertegaskan melalui Peraturan Daerah dalam keputusan di bidang Pengelolaan Barang Milik Daerah Kabupaten Bima dengan Peraturan Bupati Nomor 1 Tahun 2017 tentang Pengelolaan Barang Milik Daerah.

Objek penelitian ini merupakan salah satu kabupaten di Provinsi NTB (Nusa Tenggara Barat) yang berada diujung timur pulau Sumbawa, yakni Pemerintah Kabupaten Bima pada UPD DPPKAD (Dinas Pengelola Pendapatan, Keuangan dan Aset Daerah). Secara geografis Kabupaten Bima berada pada posisi 117040199010" Bujur Timur dan 70030" Lintang Selatan. Luas wilayah Kabupaten Bima mencapai 4.3894,40 km2 dan berpenduduk 438.522 jiwa. Secara administratif Kabupaten Bima terdiri dari 18 Kecamatan dan 168 desa, sedangkan secara tropografis wilayah Kabupaten Bima sebagian besar $(70 \%)$ merupakan dataran tinggi bertekstur pegunungan sementara sisanya $(30 \%)$ adalah daratan.
Permasalahan yang terjadi pada pemerintahan Kabupaten Bima yang sering terabaikan seperti pelaksanaan manajemen barang milik daerah yang meliputi prosedur penatausahaan inventarisasi dan identifikasi barang milik daerah secara fisik maupun yuridis yang belum terlaksanakan dengan baik. Ketidaktertiban dalam pengelolaan data base aset/barang milik daerah terutama aset berupa tanah daerah, sehingga barang milik daerah cenderung tidak dikelola untuk pemanfaatan dalam penggunaannya. Dengan demikian pemerintah daerah mengalami kesulitan untuk mengembangkan dan pemanfaatan dari pengelolaan barang milik dimasa yang akan datang, misalnya dari aspek ekonomi adalah tidak diperolehnya revenue yang sesuai dengan besar nilai aset tersebut yang dimiliki atau dengan kata lain tingkat pengembaliannya rendah.

Fenomena yang terjadi dilapangan adalah kecenderungan terbengkalainya penataan aset/barang milik daerah yang dimiliki pemerintah daerah. Ketidak jelasan penanggung-jawab pengelolaan barang milik daerah termasuk aspek pengadaan, pemanfaatan, pengadministrasian, pemeliharaan dan pengawasannya. Penyerahan pertanggungjawaban pemerintah pusat kepada pemerintah daerah sebagai konsekuensi dari desentralisasi, yang diikuti dengan penyerahan barang milik daerah sesuai dengan pembentukan otonom berupa tanah, bangunan dan aset lainnya yang seharusnya semakin menambah daftar potensi apabila dikelola dengan optimal akan memberikan nilai tambah untuk peningkatan kualitas pelayanan publik, di samping itu tentu saja akan memberikan konstribusi bagi pendapatan daerah yang secara sirkulasi berdampak pada peningkatan kesejahteraan masyarakat.

Keterbatasan sektor publik dalam memenuhi kebutuhan publik membutuhkan kerjasama dengan melibatkan pihak swasta dan masyarakat itu sendiri dalam satu ikatan hubungan yang disebut kemitraan. 
Kemitraan didasarkan oleh adanya hubungan bottom up, yaitu sebuah konsep Collaborative Governance yang percaya bahwa sebuah implementasi kebijakan akan kemungkinan berhasil jika kelompok aktoraktor dan stakeholder dilibatkan dari awal mulai proses sampai implementasi kebijakan. Hubungan ketiga aktor tersebut, aktor yang memiliki peran terbesar adalah pemerintah/negara. Menurut pandangan Rousseau (Prayogo, 2006), negara sebagai the sovereign yang memiliki kewenangan sekaligus menjadi juri dalam relasi ini dan sebagai penegak regulasi jika ada yang melanggar.

Berdasarkan uraian dari latar belakang tersebut maka diperlukan suatu kajian yang mendalam tentang strategi manajemen pengelolaan dan pemanfaatan barang milik daerah yang dimiliki/dikelola oleh pemerintah Kabupaten Bima.

\section{KAJIAN LITERATUR}

Manajemen merupakan seni dalam menyelesaiakan sesuatu melalui orang lain (Management is the art of getting things done through people) (Erni, 2005:5). Sedangkan Terry (1992:1) mengatakan bahwa manajemen merupakan suatu proses atau kerangka kerja yang melibatkan bimbingan atau pengarahan suatu kelompok orang-orang kearah tujuantujuan organisasional atau maksud-maksud yang nyata. Berdasarkan definisi tersebut maka manajemen merupakan seni mencapai sesuatu melalui orang lain dengan aktivitas perencanaan, pengorganisasian, pengendalian, penempatan, pengarahan, pemotivasian, komunikasi, pengambilan keputusan yang dilakukan oleh setiap organisasi dengan tujuan untuk mengkoordinasikan berbagai sumber daya sehingga akan menghasilkan suatu produk atau jasa secara efisien dan efektif.

New Public Management (NPM) merupakan suatu sistem manajemen desentral dengan perangkat-perangkat manajemen baru seperti controlling, benchmarking dan leanmanagement (Denhardt, J.V. 2003). New Public Management dipahami sebagai privatisasi atas aktivitas pemerintah. new public management secara umum dipahami sebagai suatu pendekatan dalam administrasi publik yang menerapkan pengetahuan dan pengalaman yang diperoleh dalam dunia manajemen dan displin yang lain untuk meningkatkan efisiensi, efektivitas kerja pelayanan publik pada birokrasi modern.

New public management (NPM) berfokus pada manajemen sektor publik yang berorientasi pada kerja, bukan pada kebijakan. Penggunaan paradigma new public management tersebut menimbulkan beberapa konsekuensi pemerintah diantaranya adalah tuntutan melakukan efisiensi, pemangkasan biaya dan kompentensi tender. New public management memberikan perubahan sektor publik, dari sistem manajemen tradisional yang terkesan kaku, birokratis dan hierarkis menjadi model manajemen sektor publik yang fleksibel dan lebih mengakomodir pasar. Perubahan tersebut bukan sekedar perubahan kecil dan sederhana, perubahan tersebut telah mengubah peran pemerintah terutama dalam hal hubungan antara pemerintah dan masyarakat (Mardiasmo, 2002:78).

Aset dalam pengertian hukum disebut benda, yang terdiri dari benda tidak bergerak maupun bergerak. Barang yang dimaksud meliputi barang tidak bergerak (tanah dan bangunan) dan bergerak, baik yang berwujud (tangible) maupun tak terwujud (intangible), yang tercakup dalam aktiva/kekayaan atau harta kekayaan dari suatu perusahaan, badan usaha, instansi atau individu perorangan dan dalam pengertian aset negara atau HKN (Harta Kekayaan Negara) juga terdiri dari barangbarang atau benda yang tersebut. Termasuk 
juga bantuan-bantuan dari luar negeri yang diperoleh secara sah (Siregar, 2004:178).

Menurut Siregar (2004:178) aset secara umum merupakan barang (thing) atau suatu barang (anything) yang mempunyai nilai ekonomi (economi value), nilai komersial (commercial value) atau nilai tukar (exahange value) yang dimiliki oleh badan usaha, instansi atau individu/kelompok. Sedangkan menurut Standar Akutansi Pemerintah (SAP), aset merupakan sumber daya ekonomi yang dikuasai dan/atau dimiliki oleh pemerintah sebagai akibat dari peristiwa sejarah dari mana manfaat ekonomi dan/atau sosia dimasa depan diharapkan dapat diperoleh, baik oleh pemerintah maupun masyarakat, serta dapat diukur dalam satuan uang, termasuk sumber daya non-keuangan yang diperlukan untuk penyediaan jasa bagi masyarakat umum dan sumber-sumber daya yang dipelihara karena sejara dan budaya.

Manajemen aset menjadi suatu bidang ilmu dalam dunia pendidikan yang muncul akibat adanya kenyataan di Indonesia yang memiliki kekayaan sumber daya alam maupun sumber daya manusia dan juga infrastruktur yang masih belum dikelola dengan baik. Oleh karena itu, segala kekayaan yang dimiliki oleh negara ini mestinya dikelola dan dijaga keberadaannya dan dalam pemanfaatannya jangan berlebihan atau over capacity.

Menurut Hariyono (2007). Pengelolaan Manajemen Aset merupakan kegiatan mengelola suatu barang yang dimiliki melaui dari perencanaan, pengadaan, operasi dan pemeliharaan serta penghapusan. Berdasarkan pada Departement of Threasury and Finance (2004). Bahwa pengertian Manajemen Aset adalah proses pengelolaan suatu barang yang memiliki nilai dan manfaat lebih dari 1 (satu) tahun yang digunakan dalam kegiatan operasional perusahaan. Agar pengelolaan barang milik daerah dapat dilakukan dengan baik dan benar, maka pejabat daerah yang diserahi tugas untuk mengelolah barang/aset daerah harus memiliki pengertian yang sama dan menggunakan dasar hukum pengelolaan yang sama pula.

Lebih lanjut Soleh dan Rochmansjad (2010:174) mengatakan bahwa aset/barang milik daerah merupakan semua kekayaan daerah baik yang dibeli maupun diperoleh dari beban Anggaran Pendapatan dan Belanja Daerah (APBD) ataupun yang berasal dari perolehan lain yang sah baik yang bergerak maupun yang tidak bergerak beserta bagian-bagiannya ataupun merupakan satuan tertentu yang dapat dinilai, dihitung, diukur atau ditimbang termasuk hewan dan tumbuh-tumbuhan tak kecuali uang dan surat-surat berharga lainnya.

Pemanfaatan barang milik daerah merupakan pendayagunaan barang daerah yang tidak dipergunakan sesuai tugas pokok dan fungsi SKPD dalam bentuk penyewaan, pinjam pakai, kerjasama pemanfaatan, bangun guna serah, bangun serah guna dan kerjasama penyediaan infrastruktur dengan tidak merubah status kepemilikan (Soleh dan Rochmansjah (2010:203). Pemanfaatan barang milik daerah yang optimal akan membuka lapangan pekerjaan, meningkatkan pendapatan masyarakat dan menambah/meningkatkan pendapatan daerah.

Pemanfaatan barang milik daerah dilakukan sesuai ketentuan Peraturan Menteri Dalam Negeri Nomor 19 Tahun 2016 Tentang Pengelolaan Barang Milik Daerah, dimana sebelumnya pemerintah pusat mengeluarkan Peraturan Pemerintah Nomor 27 Tahun 2014 Tentang Pengelolaan Barang Milik Daerah, di mana dijelaskan bahwa pemanfaatan barang milik daerah berupa tanah dan/atau bangunan yang diperlukan untuk menunjang penyelenggaraan tugas pokok dan fungsi pengguna 
barang/kuasa pengguna barang dilakukan oleh pengguna barang dengan persetujuan pengelolaan barang. Pemanfaatan barang milik daerah dilaksanakan berdasarkan pertimbangan teknis dengan memperhatikan kepentingan daerah dan kepentingan umum.

Kemitraan dalam lingkungan masyarakat Indonesia merupakan sesuatu hal yang tidak asing untuk diterapkan, karena bangsa ini sudah mengenal kemitraan sejak berabad-abad lamanya meskipun dalam skala yang sederhana, seperti gotong royong, sambat sinambat, partisipasi, mitra masyarakat desa hutan, mitra lingkungan dll. Dalam manajemen moder, baik dalam pengembangan simber daya manusia maupun pengembangan kelembagaan/usaha, kemitraan merupakan salah satu strategis yang biasa ditempuh untuk mendukung keberhasilan implementasi manajemen modern. Kemitraan tidak sekedar diterjemahan sebagai sebuah kerjasama, akan tetapi memiliki pola, memiliki nilai strategis untuk mewujudkan keberhasilan suatu lembaga dalam menerapkan manajemen modern.

Dalam penentuan indikator sebaiknya dipahami prinsip-prinsip indikator yaitu: spesifik, dapat diukur, dapat dicapai, realistis dan tepat waktu. Sedangkan pengembangan indikator melalui pendekatan program menurut Dirjen P2L \& PM dalam Kuswidanti (2008:22) dijelaskan sebagai berikut:

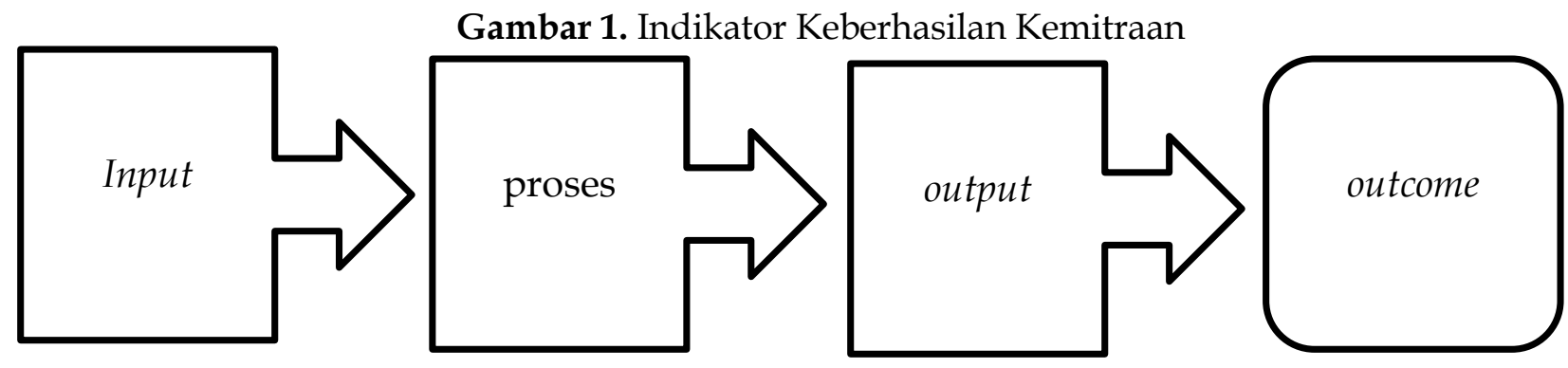

Sumber: Dirjen P2L \& PM Tahun 2008

Indikator Input. Ukuran keberhasilan input dapat diukur dari tiga indikator, yaitu terbentuknya tim, wadah, sekretariat yang ditandai dengan adanya kesempatan berkolaborasi bersama dalam kemitraan adanya sumber dana/biaya yang diperuntukkan bagi pengembangan kemitraan, adanya dokumentasi perencanaan yang telah disepakati oleh institusi terkait dan hasil evaluasi terhadap input dinilai berhasil apabila ketiga tolok ukur tersebut terbukti ada.

Indikator Proses. Ukuran keberhasilan proses dapat diukur dari indikator sebagai frekuensi dan kualitas pertemuan tim atau sesuai kebutuhan. Hasil evaluasi terhadap proses nilai berhasil, apabila tolok ukur tersebut terbukti adanya yang dilengkapi dengan agenda pertemuan, daftar hadir dan notulen hasil pertemuan.

P-JIAP: Vol. 6 (2) 2021
Indikator output. Ukuran keberhasilan output dapat diukur dari indikator sebagai berikut: jumlah kegiatan yang dikerjakan oleh institusi terkait sesuai dengan kesempatan peran masing-masing institusi. Hasil evaluasi terhadap output dinilai berhasil, apabila tolok ukur tersebut diatas terbukti ada sedangkan indikator outcome, tolok ukur keberhasilan outcome merupakan menurunnya angka permasalahan yang terjadi.

\section{METODE PENELITIAN}

Jenis penelitian ini adalah penelitian kualitatif, untuk mendapatkan deskripsi tentang pelaksanaan pengelolaan manajemen aset daerah berupa tanah sewa yang dilakukan oleh DPPKAD Kabupaten Bima, Nusa Tenggara Barat (NTB) dalam mencari fakta dan fenomena yang dikaji 
secara mendalam, menyeluruh dan alamiah tanpa adanya keberpihakan peneliti. Fokus penelitian kualitatif dimaksudkan untuk membatasi studi kualitatif, sekaligus membatasi peneliti dalam menentukan data yang relevan dan mana yang tidak relevan, antara lain; 1) Manajemen barang milik daerah berbasis kemitraan antara pemerintah, swasta dan masyarakat dengan konsep Collaborative Governance dalam pengelolaan pemanfaatan barang milik daerah pada DPPKAD Kab. Bima, ditinjau dari indikator: Input, Proses, Output dan Outcome; 2) Identifikasi dan analisis faktor yang mendukung dan menghambat pelaksanaan manajemen barang milik daerah berbasis kemitraan pada DPPKAD Kab. Bima.

Dalam hal ini yang menjadi informan sebagai sumber data primer penelitian ini antara lain Kepala DPPKADKabBima, Subbag Program dan Pelaporan DPPKAD Kabupaten Bima, Kepala Bidang Aset DPPKAD Kabupaten Bima serta warga masyarakat Kabupaten Bima. Kedua, data sekunder, yaitu data yang dikumpulan dan diperoleh dari orang lain diluar penelitian. Data sekunder dalam penelitian Manajemen Barang Milik Daerah Berbasis Kemitraan di DPPKAD Kabupaten Bima meliputi Peraturan Menteri Dalam Negeri No. 19 Tahun 2016, Peratuan Bupati Bima No. 44 Tahun 2016, Peratuan Bupati Bima No.45 Tahun 2016, Peratuan Bupati Bima No.1 Tahun 2017, dokumen dan arsip terkait Penerimaan Daerah Kabupaten Bima tahun 2019 serta profil Kabupaten Bima dalam Angka. Penelitian ini menggunakan analisis data model interaktif dari Miles, Huberman danSaldana (2014) yang meliputi:1) Data Condensation (Kondesasi data), 2) Data Display (Penyajian Data),3) Conclusion Drawing and Verification (PenarikanKesimpulan atau Verifikasi)

\section{HASIL DAN PEMBAHASAN}

Sejak masa kesultanan, tepatnya sesaat setelah dinobatkannya Sultan Abdul Kahir atau yang biasa dikenal dengan nama "LA KAI" sebagai sultan Bima yang pertama, pemerintahan Bima dijalankan sesuai dengan syariat Islam. Agama Islam menjadi agama mayoritas dengan presentase 99\%, dimana sebelumnya masyarakat Bima masih menganut kepercayaan MakambaMakimbi (animisme dan dinamisme). Kabupaten Bima sebagai salah satu dari bagian wilayah provinsi Nusa Tenggara Barat (NTB) terletak di ujung timur pulau Sumbawa. Kabuapten Bima memiliki luas wilayah mencapai 4.374,65 km2. Terletak pada 118044" BT - 119022" BT, dan 08008" 080.57" LS.

Pressman dan Widldavsky dalam Luice Cerna (2013:18) mengatakan "Passing Policies does not guarantee success on the ground if policy are not implemented well" yang maksudnya kebijakan yang disetujui tidak menjamin keberhasilan dilapangan jika kebijakan tersebut tidak diterapkan dengan baik. Berdasarkan data yang diperoleh oleh peneliti dilapangan, maka peneliti berusaha menganalisis dan menginterpretasikan data yang ada, peneliti menggunakan pendekatan kualitatif dimana metode ini ditujukan untuk melukiskan atau menggambarkan bagaimana hasil dari pelaksanaan manajemen barang milik daerah berbasis kemitraan di DPPKAD Kabupaten Bima.

Menjalin kemitraan bukanlah sebagai output atau tujuan, tetapi bukan juga sebuah proses, namun adalah sebuah sistem. Sistem adalah sekumpulan unsur / elemen yang saling berkaitan dan saling mempengaruhi dalam mencapai suatu tujuan. Untuk dapat mengetahui keberhasilan pengembangan kemitraan penulis harus melihat indikator yang dapat diukur. Dalam penentuan indikator sebaiknya dipahami prinsipprinsip indikator yaitu: spesifik, dapat diukur, dapat dicapai, realistis dan tepat waktu. Sebagai bahan kajian pembahasan hasil penelitian, penulis melakukan pengembangan indikator melalui pendekatan program menurut Dirjen P2L \& 
PM dalam Kuswidanti (2008:22) yang terdiri dari empat indikator, antara lain:

\section{Indikator Input}

Dalam wawancara dengan narasumber A, B dan C selama di DPPKAD Kabupaten Bima didapatkan temuan bahwa belum adanya pendanaan khusus kemitraan, sudah terpenuhinya fasilitasfasilitas pendukung kinerja, tingkat pendidikan pegawai DPPKAD Kabupaten Bima, jika dikaji berdasarkan teori yang ada menunjukkan bahwa indikator input dari pelaksanaan manajemen barang milik daerah berbasis kemitraan di DPPKAD Kabupaten Bima sudah tergolong baik, didukung oleh sumberdaya yang ada. Namun dirasa masih bisa dimaksimalkan jika dukungan sumberdaya finansial yang ada dalam tubuh DPPKAD Kabupaten Bima bisa lebih dikembangkan. Hal ini akan mendukung terjadinya input yang baik dalam menjalankan proses kemitraan yang baik dalam pengelolaan barang milik daerah oleh DPPKAD Kabupaten Bima.

\section{Indikator Proses}

Membahas mengenai interaksi antar aktor berarti secara tidak langsung menyangkut pembahasan mengenai konsep good governance (tata pemerintahan yang baik) yang mana dalam pembahasan good governance dijelaskan bagaimana hubungan antar aktor yakni pemerintah, swasta dan masyarakat. Berdasarkan hasil wawancara, observasi dan kajian teori tersebut peneliti dapat menarik kesimpulan bahwa DPPKAD Kabupaten Bima selaku pembantu kepala daerah dalam melakukan pengelolaan aset tetap daerah sudah melakukan tahapan pembinaan, pengawasan dan pengendelian sesuai dengan Permendagri No.19 Tahun 2016, dan menjalankan fungsi pemerintah dengan baik. Namun yang menjadi kurang sempurna adalah tidak adanya keterlibatan sektor swasta sehingga belum menunjukkan adanya Collaborative Governance. Menurut analisis peneliti, belum adanya aturan yang secara khusus membahas dan mengatur tentang kemitraan dengan pihak swasta maupun masyarakat, khususnya bagi DPPKAD Kabupaten Bima, menghambat terjadinya proses interaksi tersebut.

\section{Indikator output}

Hasil evaluasi terhadap output dinilai berhasil, apabila tolak ukur tersebut diatas terbukti ada. Kolaborasi antarpemerintahan (collaborative governance) adalah suatu bentuk tata kelola pemerintahan, dimana satu atau beberapa institusi publik melibatkan stakeholders di luar pemerintah secara langsung dalam proses pengambilan keputusan kolektif, berorientasi konsensus, dan deliberatif serta berupaya untuk mengimplementasikan kebijakan secara kolektif (Ansell \& Gash, 2002: 543).Dari data hasil penelitian dan kajian teori dapat diketahui bahwa program kegiatan yang dilakukan oleh DPPKAD Kabupaten Bima berkaitan dengan pengembangan peran dari kemitraan SKPD di lingkungan pemerintah Kabupaten Bima. DPPKAD menjalankan fungsi monitoring terkait pengelolaan aset yang nantinya berdampak kepada kinerja DPPKAD Kabupaten Bima sendiri. Hasil observasi peneliti menunjukkan bahwa kegiatan yang ada pada DPPKAD sudah ada, namun secara kualitas dan kuantitas dirasa kurang. Pada tahap ini pengukuran output selayaknya dapat dikaji lebih mendalam melalui penelitian lanjutan di masing-masing SKPD yang menjadi mitra DPPKAD.

\section{Indikator Outcome}

Dalam studi kasus di penelitian ini, yang akan dikaji dan dilihat keberhasilannya adalah outcome berupa peningkatan Pendapatan Asli Daerah Kabupaten Bima dengan penerapan proses manajemen pengelolaan barang milik daerah berbasis kemitraan di DPPKAD 
Kabupaten Bima. Chief J.O. Udoji yang menyatakan bahwa dalam proses kebijakan publik, implementasi kebijakan adalah sesuatu yang penting, bahkan jauh lebih penting daripada pembuatan kebijakan. Implementasi kebijakan merupakan jembatan yang menghubungkan formulasi kebijakan dengan hasil (outcome) kebijakan yang diharapkan (Nurhajadmo,2008:216).

Tolak ukur keberhasilan outcome merupakan hasil target yang diharapkan oleh DPPKAD Kabupaten Bima. Dalam pengelolaan Barang Daerah khususnya di sektor sewa tanah yang diharapkan adalah terjadinya kenaikan pendapatan asli daerah kabupaten Bima dari sektor tersebut. Data yang diperoleh peneliti menunjukkan penerimaan daerah dari sektor sewa tanah pada tahun 2019 masih kurang Rp. 295.303.022 atau sebesar 95.08\% dari Anggaran yang diharapkan sebesar Rp.6.000.000.000 di tahun 2019. Dibandingkan dengan tahun 2018 yang mengalami kelebihan sebesar Rp. 98.384.108 atau sebesar $103.78 \%$ dari total penganggaran Rp. 2.600.000.000.

Dari data di lapangan dan hasil kajian secara teoritis diatas terjadi kenaikan penganggaran penerimaan daerah dari sektor sewa tanah dari tahun 2018 ke tahun 2019. Hal ini disimpulkan berdasarkan data pencapaian penganggaran di tahun 2018 dan 2019 di Kabupaten Bima. Namun pada tahun 2019, pencapaian masih berada dibawah harapan. Hal ini dirasa tidak maksimal karena kurangnya sosialisasi pada tahap input sehingga menyebabkan tidak terjadinya peningkatan pendapatan di Kabupaten Bima. Besar kemungkinan akan terjadi kenaikan pendapatan asli daerah yang lebih maksimal dari sektor sewa tanah jika pemerintah Kabupaten Bima melalui DPPKAD melakukan kegiatan kemitraan dengan lebih maksimal.

\section{Faktor Pendukung dan Penghambat}

Pelaksanaan manajemen barang milik daerah oleh DPPKAD Kabupaten Bima akan berhasil jika didukung oleh faktor-faktor yang membuat kebijakan itu berjalan sesuai dengan yang diharapkan. Faktor-faktor itu berupa faktor pendukung dan penghambat. Dalam implementasinya faktor pendukung manajemen barang milik daerah oleh DPPKAD Kabupaten Bima adalah kualitas / tingkat pendidikan sumber daya manusia yang baik, lingkungan kerja yang mendukung, dan sarana prasarana yang memadai. Sedangkan yang menjadi faktor penghambat adalah peraturan yang tidak menjangkau pada proses kemitraan dan tingkat sosialisasi program yang rendah.

\section{PENUTUP}

Berdasarkan hasil penelitian berupa temuan di lapangan dan hasil analisis data menggunakan model interaktif, maka dapat ditarik kesimpulan bahwa secara umum manajemen barang milik daerah berbasis kemitraan dalam meningkatkan sumber pendapatan daerah (Studi Terhadap Pemanfaatan Barang Milik Daerah Berupa Tanah pada DPPKAD Kabupaten Bima) sudah berjalan dengan baik namun belum maksimal, dilihat dari ke-empat indikator yang ada yaitu indikator; 1).Input, 2).Proses, 3).Output dan 4).Outcome. Didukung oleh beberapa faktor antara lain 1).Kualitas SDM yang baik, 2).Lingkungan kerja yang baik, dan 3).Sarana prasarana yang memadai. Sedangkan yang menjadi faktor penghambat adalah; 1).Peraturan yang tidak menjangkau pada proses kemitraan dan 2).Tingkat sosialisasi program yang rendah.

\section{DAFTAR PUSTAKA}

Ansell. Chris \& Gash. A, 2008. Collaborative Governance in Theory and Practice. Journal of Public Administration Research and Theory. 
Erni Trisnawati, Sule. 2005. Pengantar Manajemen,Jakarta. Kencana.

Denhardt. Pol ert B And Denhardt, Janet V. 2003. The New Public Service, Service, Serving Not Steering. England: M.E Sharpe.

Cer na, Lucie. 2013.The Natureof PolicyChange and Implementation: ARevi ew of Different Theoret ical Approaches,Organization for economic co operation and development.

Mardiasmo, 2002.Otonomi dan Manajemen Keuangan Daerah. Penerbit Andi Yogyakarta.

Moleong, Lexy J. 2015. Metodologi Penelitaian Kualitataif. Remaja Rosdakarya, Bandung.

Miles,M.B, Huberman,A.M, dan Saldana,J. 2014.Qualitative Data Analysis, A Methods Sourcebook,Edition 3. USA: Sage Publications. Terjemahan Tjetjep Rohindi Rohidi, UI-Press.
Notoatmodjo, Soekidjo. 2003. Pendidikan Dan Perilaku Kesehatan. Rineka Cipta. Jakarta.

R.Terry, George. 1992. Dasar-Dasar Manajemen. Jakarta: Bumi Aksara.

Sole. C dan Rochmansjah. H. 2010. Pengelolaan Keuangan dan Aset Daerah. CV. GAZA PUBLISHING, Bnadung.

Sirega. D, 2004. Manajemen Aset. PT Gramedia, Jakarta.

Sulistiyani, Ambar. T, 2004. Kemitraan dan Mode-Model Pemberdayaan. Gava Media.

https://bimakab.bps.go.id/linkTabelStatis /view/id/165.

Peraturan Menteri Dalam Negeri No 19/2016, dengan Peraturan Pemerintah No. 27/2014 Tentang Pengelolaan Barang Milik Negara/Daerah.

Peraturan Pemerintah Kabupaten Bima dengan Peraturan Bupati Nomor 1 Tahun 2017 tentang pengelolaan Barang Milik Daerah. 